\title{
Tsunami hazards in the Eastern Mediterranean: strong earthquakes and tsunamis in the East Hellenic Arc and Trench system
}

\author{
G. A. Papadopoulos, E. Daskalaki, A. Fokaefs, and N. Giraleas \\ Institute of Geodynamics, National Observatory of Athens, 11810 Athens, Greece \\ Received: 16 October 2006 - Revised: 8 January 2007 - Accepted: 8 January 2007 - Published: 16 January 2007
}

\begin{abstract}
Data on tsunami phenomena occurring in the East Hellenic Arc and Trench system (HA-T) from antiquity up to the present have been updated, critically evaluated and compiled in the standard GITEC format developed in the last decade for the New European Tsunami Catalogue. New field observations are presented for the tsunamis of 9 February 1948 and 24 March 2002. From the 18 tsunamis reported eight are rather well-documented while another nine remain doubtful. The mean recurrence of strong tsunamis is likely equal to about 142 years. Most of the tsunamis documented are caused by strong earthquakes occurring in the area offshore Rhodes to the east or northeast of the island. However, there are large earthquakes near Rhodes that do not cause tsunamis, like the 1926 and 1957 ones, which is of particular importance for the tsunami hazard assessment.
\end{abstract}

\section{Introduction}

The area of East Mediterranean Sea is characterized by very high seismicity, the Hellenic Arc and Trench system, hereafter called HA-T for reasons of brevity, being one of the most active seismogenic structures. Many large, shallow and intermediate-depth earthquakes have been reported there in the historical past and recorded during the instrumental era of seismology. Many of these earthquakes generated strong tsunamis some of them being propagated at large distances in the East Mediterranean basin (Galanopoulos, 1960; Ambraseys, 1962; Antonopoulos, 1980; Papadopoulos and Chalkis, 1984; Soloviev, 1990; Soloviev et al., 2000; Papazachos and Papazachou, 1997; Papadopoulos, 2001).

In an effort to standardize the assessment of tsunami hazard in the sense of repeat times of tsunami events, relevant data were compiled and published for the Corinth Gulf, Cen-

Correspondence to: G. A. Papadopoulos

(g.papad@gein.noa.gr) tral Greece, as well as for Cyprus and the Levantine Sea (Papadopoulos, 2003; Fokaefs and Papadopoulos, 2006). Data were compiled and re-evaluated by following the format of the New European Tsunami Catalogue produced by specialists in the frame of the CEC GITEC and GITEC-TWO research projects (e.g. Tinti and Maramai, 1996; Papadopoulos, 2003). In addition, the data compiled were used for tsunami hazard assessment in the areas mentioned above.

This paper is a follow-up of this effort and focuses in the eastern segment of HA-T (Fig. 1) and includes the area of Dodecanese island complex, to the east of Crete Island, as well as the southwest part of Turkey. Data were collected and evaluated from historical documentary sources for most of the events examined. Many reviews, evaluations, books and catalogues were also taken into account (a short list includes Galanopoulos, 1960; Ambraseys, 1962; Ben-Menahem, 1979; Antonopoulos, 1980; Papadopoulos and Chalkis, 1984; Chatzivasiliou, 1989; Soloviev, 1990; Evagelatou-Notara, 1993; Ambraseys et al., 1994; Amiran et al., 1994; Ambraseys and Finkel, 1995; Guidoboni et al., 1994; Papachristodoulou, 1994; Papazachos and Papazachou, 1997; Soloviev et al., 2000; Papadopoulos, 2001). New field observations are presented for a tsunami event that inundated coastal segments of Karpathos Island on 1948. A recent event observed in Rhodes on 24 March 2002 is described and documented from field survey. In addition, three tsunami sediment layers that were discovered in Dalaman, SW Turkey coast, and were attributed to three historically documented tsunamis having their sources in HA-T (Papadopoulos et al., 2004) are discussed.

Published by Copernicus GmbH on behalf of the European Geosciences Union. 


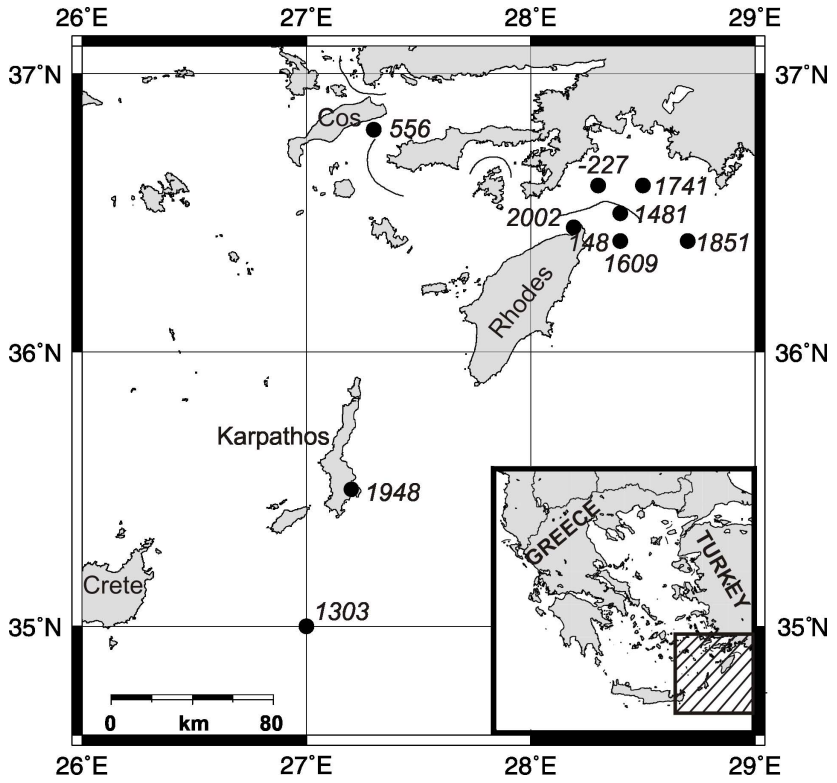

Fig. 1. Epicenters of eight tsunamigenic earthquakes and one landslide-induced tsunami (2002) listed in Table 1 and analyzed in the text. Only ten out of eighteen epicenters have been mapped since the rest are quite doubtful. Each source is accompanied by the year of occurrence of the respective tsunami event.

\section{A new tsunami catalogue}

The tsunami catalogue presented here is a Quick-Look Catalogue (QLC) structured in three sections: the Quick-Look Table (QLT), the Quick-Look Accounts File (QLAF) and the References File (RF). In this paper, RF consists of the sections of Historical Sources and References. In the Mediterranean Sea, tsunami intensity, $k$, is traditionally estimated according to the 6-grade Sieberg-Ambraseys scale (Ambraseys, 1962). In this paper, tsunami events were re-evaluated as for their size, that is the maximum tsunami intensity, according to both the classic 6-grade scale and the new 12-grade tsunami intensity scale introduced by Papadopoulos and Imamura (2001).

\subsection{The Quick-Look Table}

The QLT is arranged in Table 1 which shows that tsunami events were reported as early as $227 \mathrm{BC}$ while the last event was observed on 2002. Uncertainty in location is estimated to be about 27 or 16 minutes which for the Greek area is about $50 \mathrm{~km}$ or $30 \mathrm{~km}$, respectively, given that one degree of latitude equals to $111 \mathrm{~km}$.

\subsection{The Quick-Look accounts file}

This is the second section of the QLC and is arranged as follows: [code number] date: year (- stands for $\mathrm{BC}$ ), month, day (in New Style)/place

coordinates of the source: geographic latitude $(\mathrm{N}) /$ longitude (E) in degrees and minutes

cause: see key in Table 1

tsunami intensity: in 6-grade scale/in 12-grade scale reliability: scales from 1 to 4 (see Table 1).

In the next lines 18 events are shortly described. Epicenters of tsunamigenic earthquakes are plotted in Fig. 1. Greek islands in HA-T as well as the coast of SW Turkey were also affected by other two large tsunamis which are not included in the present catalogue because their sources are located in the Cyclades island complex, South Aegean Sea, that is outside the HA-T. The first is the large tsunami of 9 July 1956 caused by a $M_{S}=7.4$ tectonic earthquake (Galanopoulos, 1957; Perissoratis and Papadopoulos, 1999). The second is the Minoan tsunami of 17 th century BC produced by the great Late Bronze Age eruption of Thera (Santorini) volcano (Minoura et al., 2000).

[1] -227, Rhodes island coordinates: 363628 15, cause: ER tsunami intensity: ?, reliability: 1

Classic writers, like Polyvios (202-120 BC) and Pausanias (2nd century $\mathrm{AD}$ ), reported that a strong earthquake destructed the city of Rhodes around $227 \mathrm{BC}$ and caused the collapse of the famous Colossus of Helios. Sieberg (1932) stated that a seismic-sea wave was associated with the earthquake but this is not justified by the available historical documentation.

[2] 148, Rhodes island coordinates: 362428 20, cause: ER

tsunami intensity: $3 / 6$, reliability: 3

Pausanias reported on a strong earthquake which caused extensive destruction in the city of Rhodes. In the rhetorical speech "Rodiakos" of Aristides Aelius (129-189 AD), communicated to the citizens of Rhodes, a strong tsunami caused by the earthquake is described (see passages 20-26): “... and I remember that in that fatal noon, when the calamity that happened to you started, when the sea was calm,... and all the earthquake force was directed against the city... Then the sea water retreated and the ports dried up... and the ports became as the dry ground... And everything happened at the same moment: the earthquake of the sea, the clouds, the roaring, the lamentations, the noise of the dead bodies, the ground subsidence... Everything had collapsed...”. In addition, the speech of Aelius makes clear that the islands of Symi (Dodecanese) and Serifos (Cyclades) were not destructed by the earthquake as claimed by Papazachos and Papazachou (1997) who apparently misunderstood passage 38 of the speech. The estimates for the year of occurrence of this earthquake and tsunami event range about seven years around 148. Papachristodoulou (1994) prefers to call it "the large shock of the middle of 2 nd century $A D$ ". 
Table 1. Tsunami catalogue of the eastern Hellenic Arc and Trench. Key: ID = identification number, YY = year, MM = month, DD = day, $\mathrm{hh}=$ hour, $\mathrm{mm}=$ minute, $\mathrm{ss}=$ second, Rel = reliability of the time of occurrence, Region M1 = Greece and adjacent regions as defined in the European Tsunami Catalogue, Lat = north latitude, Long = east longitude (both in degrees and minutes), Rel $=$ accuracy of the location in minutes, $\mathrm{I}=$ seismic intensity in $\mathrm{MM}, \mathrm{M}=$ surface-wave magnitude, $\mathrm{H}=$ focal depth (in $\mathrm{km}$ ), $\mathrm{n}=$ shallow event (when the tsunami was due to an earthquake event), Runup = maximum vertical tsunami run-up reported (in cm), $\mathrm{k}=$ tsunami intensity (in Sieberg-Ambraseys 6-grade scale), ), $\mathrm{K}=$ tsunami intensity (in Papadopoulos-Imamura 12-grade scale), Rel = reliability of the tsunami event, Y/N = an indication on whether the tsunami parameters were revised $(\mathrm{Y})$ or not $(\mathrm{N})$ with respect to previous catalogues. The reliability of the time of occurrence is measured in units of the last entry of the time of occurrence (e.g. in years for the event number 1, in months for the event number 9, in days for the event number 10, hours for the event number 5, etc.). The genesis causes classification are those adopted by the GITEC group: ER $=$ submarine earthquake, GS = gravitative marine slide. For the reliability of the tsunami events a modified version of the tsunami reliability scale of Iida (1984) was adopted $(0=$ very improbable tsunami, $1=$ improbable tsunami, $2=$ questionable tsunami, $3=$ probable tsunami, 4 = definite tsunami). Some additional symbol explanation is needed: (+) after a particular value means "equal to or larger than"; (-) after a particular value means "equal to or less than"; - before the year of occurrence means BC.

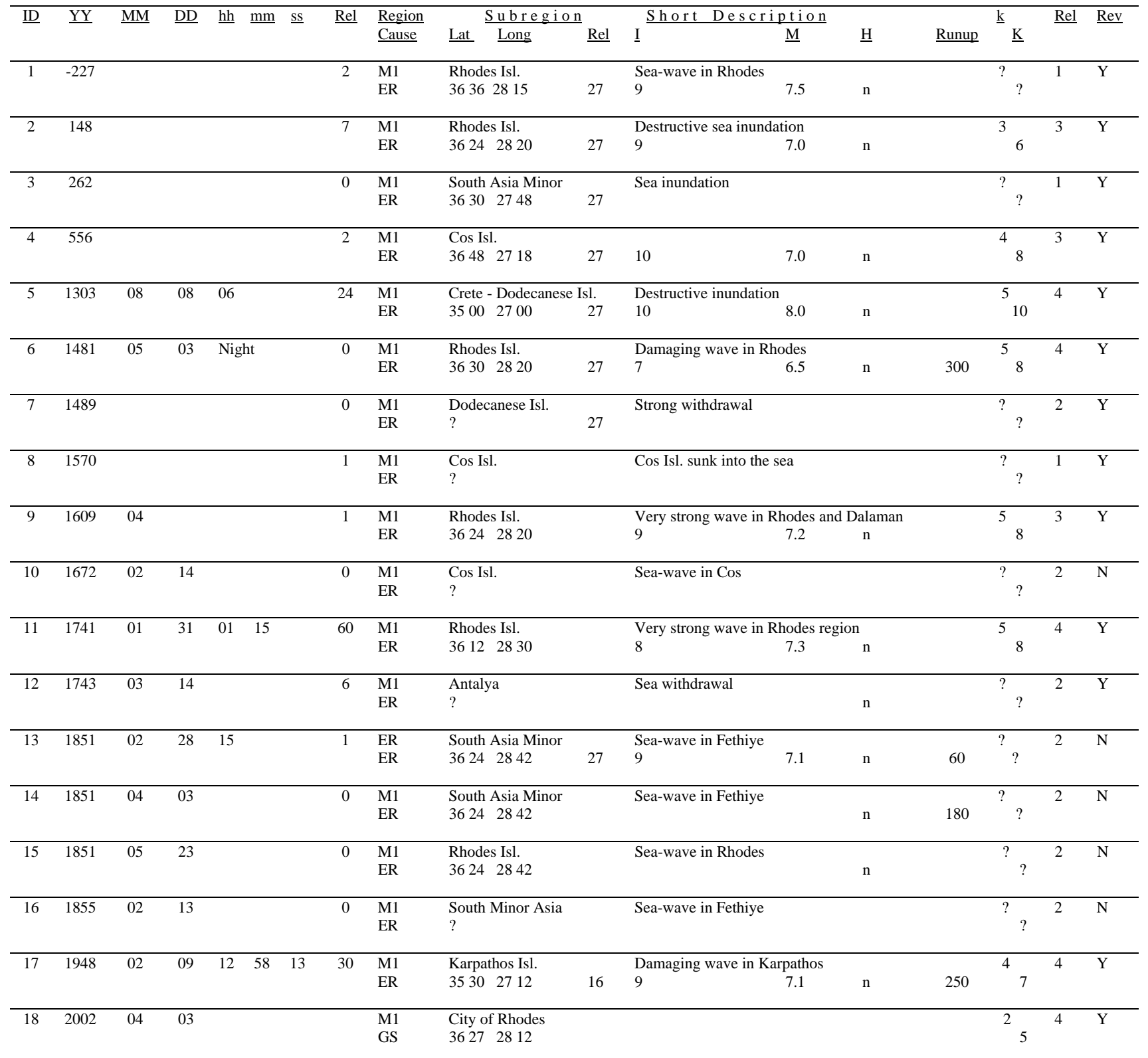


[3] 262, South Asia Minor

coordinates: 363027 48, cause: ER

tsunami intensity: ?, reliability: 1

The Historia Augusta records that during the consulship of Gallienus and Faustinianus, there were a number of serious disasters in various parts of the Mediterranean, namely at Rome, and in Libya and Asia Minor (Guidoboni et al., 1994) (see also reviews in Ambraseys, 1962 and Antonopoulos, 1980). However, documents concerning earthquakes and associated sea disturbances remain quite uncertain.

[4] 556, Cos island

coordinates: 364827 18, cause: ER

tsunami intensity: 4/8, reliability: 3

Agathias (536-582), who visited the island of Cos soon after the occurrence of a destructive earthquake, reported that the island of Cos “... was shaken and only a very small part of it saved, while the rest part collapsed... The sea rose up greatly and inundated the buildings along the coast and caused destruction to human beings and their property... ". This event occurred around the year 556 but the exact date remains uncertain.

[5] 130308 08, Crete - Dodecancese islands

coordinates: 350027 00, cause: ER

tsunami intensity: 5/10, reliability: 4

Many historical documents (see reviews in EvagelatouNotara, 1993; Guidoboni and Comastri, 1997) indicate that this was a very large tsunamigenic earthquake that ruptured the eastern segment of the Hellenic arc between Crete and Rhodes islands. A large tsunami attacked violently Iraklion (Handaka), the capital city of Crete, north coast of the island. The sea swept into the city with such force that it destructed buildings and killed inhabitants. In Alexandria and Bab-Al-Bahr, Egypt, the sea inundated the coastal zone and caused destruction to port facilities. The wave reached to Acre, Israel, where the sea flooded the shore and people were swept away and drowned by the huge wave (Amiran et al., 1994). According to Ambraseys et al. (1994) "There was also widespread destruction and a damaging seismic seawave in Rhodes and along the coast of Palestine, particularly off Acre". However, the exhaustive reviews of EvagelatouNotara (1993) and Guidoboni and Comastri (1997) do not support that Rhodes was damaged by that tsunami. On the other hand, the lower of the three tsunami sediment layers found in Dalaman, SW Turkey, could be attributed to the 1303 tsunami (Papadopoulos et al., 2004).

[6] 148105 03, Rhodes island

coordinates: 363028 20, cause: ER

tsunami intensity: 5/8, reliability: 4

According to Ambraseys et al. (1994), a strong shock of 15 March 1481 ruined Rhodes and Cyprus, setting off damaging sea-wave on the coast of Antalya, SW Turkey. However, from a detailed review of historical documents, EvagelatouNotara (1993) concluded that an earthquake sequence started on 15 March 1481 and continued up to the January of 1482 but the two strongest events, that caused destruction with many victims in the city of Rhodes, occurred on 3 May and 3 October 1481. The shock of the evening of 3 May caused a $3 \mathrm{~m}$ high tsunami that flooded the coast while a ship that was moved ashore was smashed in a reef and sank with all its crew (Coronelli and Parisotti, 1688). Bishop of Methoni Ioannis Plousiadinos (1429-1500), in his ecclesiastic speech "Moaning of Theotokos", code IV 434, Bibliothèque Royale Albert $\mathrm{I}^{\mathrm{er}}$, Brussels, dated between 1488 and 1492, describes the 1481 tsunami as follows: "... What happened in Rhodes is that the sea water penetrated inland... And the sea came out of its limits as it rose up greatly and inundated the city. Then the sea returned to its normal place..." (Vasiliou, 1980). The tsunami was reported as far away as the Levantine coasts (Ben-Menahem, 1979). Radiocarbon dating of the medium tsunami sediment layer found in Dalaman indicates deposition in $1473 \pm 46 \mathrm{AD}$, which fits well-enough the 1481 event (Papadopoulos et al., 2004).

[7] 1489, Dodecanese islands

coordinates: ?, cause: ER

tsunami intensity: ?, reliability: 2

This is a questionable earthquake and tsunami event described by Leonardo da Vinci to have occurred in 1489: "In (fourteen hundred) and 89 there was an earthquake in the sea of Adalia (Antalya, south of Anatolia) near Rhodes, which opened the (floor of the) sea, and into this opening such a torrent water poured that for more than three hours the floor of the sea was uncovered by the reason of the water which was lost in it, and then it closed (the sea coming) its former level" (see reviews in Baratta, 1903; Ambraseys, 1962; Antonopoulos, 1980).

[8] 1570, Cos island coordinates: ?, cause: ER tsunami intensity: ?, reliability: 1

On 1570 an earthquake is said to have occurred in Rhodes, while on 1571 the island of Stanchio (Cos) sunk into the sea because of an earthquake. Ambraseys and Finkel (1995) who reviewed the relevant historical sources suspect that the 1571 shock may be that of 1570 . In any case, it looks like quite questionable that a tsunami occurred in associations with that seismic event.

[9] 1609 04, Rhodes island coordinates: 36242820 cause: ER tsunami intensity: 5/8, reliability: 3

A large earthquake and tsunami event caused destruction in the city of Rhodes. In fact, historical documentation compiled by Ambraseys and Finkel (1995) makes clear that "... half of the town, including the castle was ruined, and (an exaggerated figure of) over 10000 people were reported 
drowned by a sea-wave... This appears to have been a great earthquake, felt also in various places in Egypt and the Syrian coast but further details are lacking”. However, the 1609 tsunami is missing from the Dalaman sedimentary stratigraphy analyzed by Papadopoulos et al. (2004).

[10] 16720214 , Cos island

coordinates: ?, cause: ER

tsunami intensity: ?, reliability: 2

This was a strong earthquake reported to have caused destructive effects not only in the islands of Lesvos and Tenedos, NE Aegean Sea, but also as far away as Cos island, SE Aegean Sea, where a sea-wave is said that followed the shock (Sieberg, 1932; Montandon, 1953; Ambraseys and Finkel, 1995). It is rather questionable, however, if a single earthquake was capable to cause destruction in such a large area extending from the north Aegean Sea to the south Aegean Sea.

[11] 174101 31, Rhodes island coordinates: 36122830 cause: ER tsunami intensity: 5/8, reliability: 4

According to Ambraseys et al. (1994), this earthquake originated between Rhodes and Cyprus, where minarets fell and church of Santa Sophia in Famagusta was damaged; the shock caused panic in both islands and sporadic damage in Crete. This was a large, destructive and tsunamigenic earthquake with an epicenter offshore Rhodes: “...As a result of the earthquake, the sea in Rhodes retreated and then flooded the coast 12 times with great violence, submerging the coast opposite the island and destroying five or six villages located a kilometer inland" (Ambraseys and Finkel, 1995). This piece of historical information is consistent with the result obtained by Papadopoulos et al. (2006) that the upper tsunami sediment layer found in Dalaman could be attributed to the 1741 tsunami.

[12] 174303 8-20, Antalya

coordinates: ? cause: ER

tsunami intensity: ?, reliability: 2

A report from Cyprus, dated 4 April 1743 and reviewed by Ambraseys and Finkel (1995), says that "... I have been informed from Satalia (Antalya) that from the 8th to 20th of the month there were terrible earthquakes as a result of which the port dried up for some time, many houses collapsed as well as part of the walls at different places which fell on the consul's house, destroying it. Many villages were lost in this earthquake and a mountain opposite that, which lies west of the islet of Rachat ( $\left.R e^{\circ} a t\right)$, sunk completely". This report is rather convincing as for the strong destructive earthquakes that shook the area of Antalya to the east of Rhodes. However, the piece of information that "the port dried up for some time" does not imply beyond doubt that there was a tsunami.
[13] 185102 28, South Asia Minor coordinates: 36242842 cause: ER tsunami intensity: ?, reliability: 2

A very strong earthquake caused destruction in Fethiye (Makre), SW Turkey, and in Rhodes (Ambraseys et al., 1994; Papazachos and Papazachou, 1997). Aftershocks felt in both Rhodes and Makre continued till the middle of 1852. Some authors, such as Ambraseys (1962) and Antonopoulos (1980), based on Perrey (1855), supported that in Makre the coast was flooded about $0.6 \mathrm{~m}$ above the normal sea-water level. However, from Perrey's account is not clear that a tsunami occurred. This remark is also valid for the subsequent events of 03.04.1851, 23.05.1851 and 13.02.1855.

[14] 185104 03, South Asia Minor

coordinates: 362428 42, cause: ER

tsunami intensity: ?, reliability: 2

This was possibly a strong aftershock of the 28 February 1851 earthquake (Ambraseys et al., 1994). Doubtful information for a $1.8 \mathrm{~m}$ high inundation in Fethiye (see comment in event 13).

[15] 185105 23, Rhodes island

coordinates: 362428 42, cause: ER

tsunami intensity: ?, reliability: 2

This was possibly another strong aftershock of the 28 February 1851 earthquake. Doubtful information for an inundation in Rhodes and the nearby island of Chalki was reported (see comment in event 13).

[16] 185502 13, South Asia Minor

coordinates: ?, cause: ER

tsunami intensity: ?, reliability: 2

Doubtful inundation in Fethiye was reported by Schmidt (1879), Perrey (1855) (see comment in event 13).

[17] 194802 09, Karpathos island coordinates: 353027 12, cause: ER tsunami intensity: $4 / 7$, reliability: 4

Galanopoulos $(1955,1960)$ reported that destruction was caused near Pigadia, Karpathos Island, by both the earthquake and "... a huge seismic sea-wave that penetrated inland $1 \mathrm{~km}$ " and that the first motion of the sea was withdrawal. The first author of this paper conducted a field survey in Karpathos from 8 to 10 August 2004, reviewed with eyewitnesses of the tsunami event and located observation points by hand GPS device. In Pigadia bay (Fig. 2), the main port of Karpathos, SE side of the island, the writer Mrs Fotini Makri (born in 1915) and other eyewitnesses reported that the first tsunami wave arrived about 5 to $10 \mathrm{~min}$ after the earthquake. The wave overtopped the fountain $\left(35^{\circ} 3029.2 \mathrm{~N}\right.$, $27^{\circ} 1254.1 \mathrm{E}$ ), penetrated inland up to Mrs. Makri's house, that is about $50 \mathrm{~m}$ from the fountain or about $60 \mathrm{~m}$ from the shoreline. Sea-weeds were left behind. Eyewitnesses' ac- 


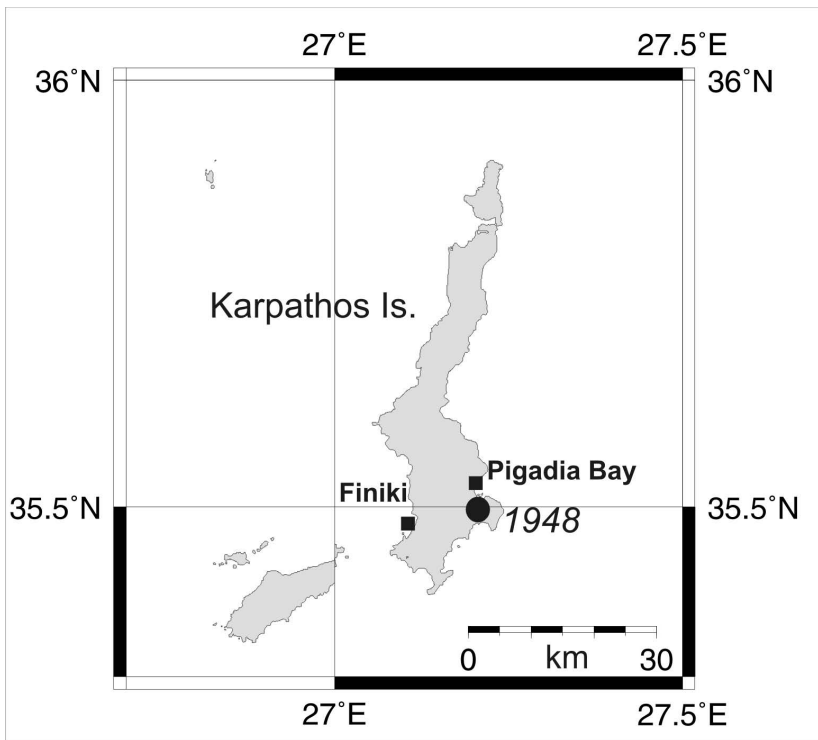

Fig. 2. The earthquake of 1948 generated a local tsunami that was observed in the coastal zones of Pigadia Bay and Finiki Bay.

counts, as well as pictures of Pigadia bay published by Makri (1999), indicate that the fountain was elevated on a wall about $2.5 \mathrm{~m}$ above the mean sea level (a.m.s.l.). Many vessels were moved ashore and destructed. Houses along the Pigadia coast were flooded and doors were broken by the wave. The sea disturbance continued for several hours. Further to northwest, in the oil-press of Mr M. Sarris $\left(35^{\circ} 3035.6 \mathrm{~N}\right.$, $27^{\circ} 1216.1 \mathrm{E}$ ) and in the mouth of a nearby small local river $\left(35^{\circ} 3036.5 \mathrm{~N}, 27^{\circ} 1221.1 \mathrm{E}\right)$, the ground is flat and slightly elevated above the sea level, which makes the area prone to tsunami inundation. In fact, eyewitnesses reported that the 1948 wave penetrated inland about $250 \mathrm{~m}$, while fishes were left behind up to a distance of about $200 \mathrm{~m}$ from the shoreline. It was also said that tsunami inundation was observed in Finiki, a small fish village in the SW side of Karpathos. Ambraseys (1988) reported that the tsunami caused considerable damage on the southwest coast of Rhodes and Papazachos and Papazachou (1997) repeated uncritically this information which we were unable to verify. Against possible tsunami damage in Rhodes is that the southwest coast of this island was and still is scarcely populated. An explanation is that Ambraseys (1988) misunderstood that the tsunami reached the southwest part of Karpathos, that is Finiki, as reported by eyewitnesses.

The results of the field survey are useful in understanding more precisely parameters of the 1948 tsunami, such as the wave height, being about $2.5 \mathrm{~m}$ in Pigadia, penetration inland, being about $250 \mathrm{~m}$ at maximum to the west of Pigadia, and time of arrival after the earthquake occurrence, ranging between 5 and $10 \mathrm{~min}$. Knowledge of such parameters are of importance to control results of future studies concerning tsunami inundation by simulation techniques as well as de-

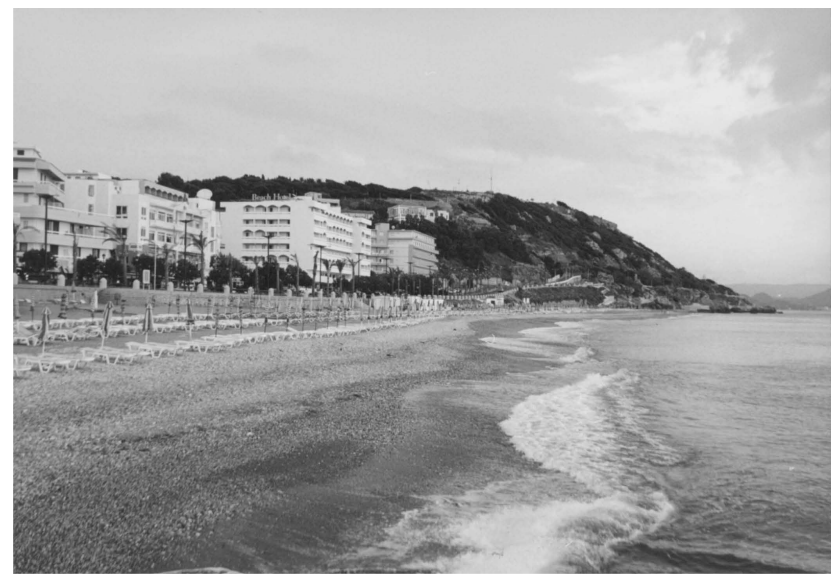

Fig. 3. View of the coastal segment of the city of Rhodes inundated by the local tsunami of 24 March 2002.

velopment of tsunami risk mapping.

[18] 200224 03, city of Rhodes

coordinates: 362728 12, cause: GS

tsunami intensity: $2 / 5$, reliability: 4

Sea-waves 3-4 $\mathrm{m}$ high were reported along the coastal zone of the city of Rhodes, during the evening of 24 March 2002 (local press reports, 25 March 2002). Unfortunately, the tidegauge of the Rhodes port authority was not in operation at that time and, therefore, the waves were not instrumentally recorded. The waves overtopped an elevated wall, which protects the coastal street from sea waves, and inundated a coastal segment as long as $2 \mathrm{~km}$ from about Grand Hotel to Psaropoula, NW side of Rhodes city (Fig. 3). Some damage was noted in several stores while small objects were drifted inland by the waves. In a field survey conducted in 23 May 2003 the wall height was measured by optical theodolite and found to range between 3 and $4 \mathrm{~m}$ a.m.s.l. As for the origin of the tsunami it is worth noting that no earthquake was recorded before or after its occurrence in the broad region of Rhodes, which may exclude seismicity as a possible triggering agent of the waves. In addition, according to the National Meteorological Survey of Greece the wind intensity did not exceed degree 6 in Beaufort scale, which may exclude the case of a storm surge. One possible explanation is that aseismic submarine slides may have caused the waves. This is in accordance with that local fishermen reported to the author that the days after the event they realized a significant increase of the sea depth at about $1 \mathrm{~km}$ offshore of the coast where the waves were observed.

\section{Tsunami recurrence}

Tsunami data in the east HA-T may be complete for very strong tsunamis $(k / K \geq 4 / 7)$ since $1300 \mathrm{AD}$, that is in about the last 710 years with five events reported (Fig. 4). Then, 

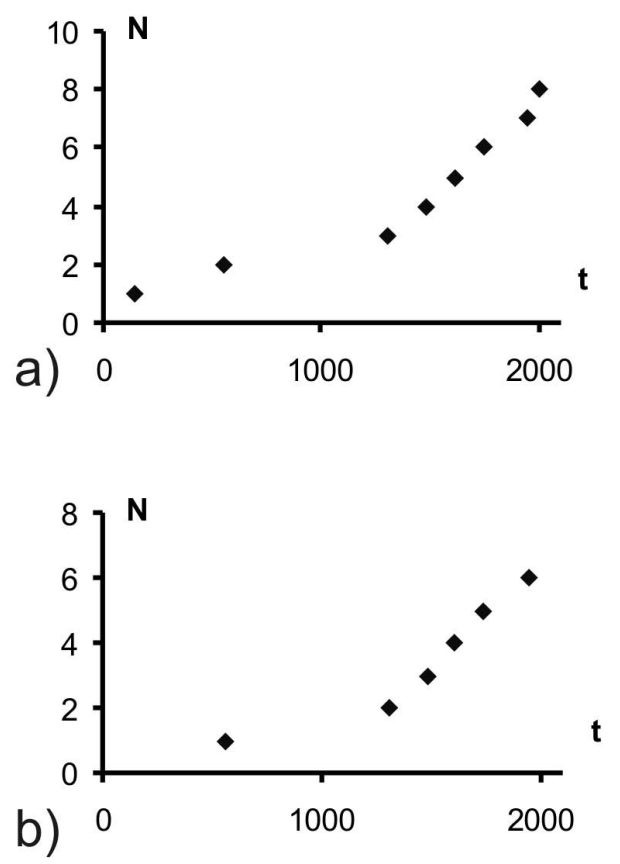

Fig. 4. Cumulative number of the tsunami events that tsunami intensity has been assigned (see data in Table 1): all tsunami events (a), tsunami events with intensity $k / K \geq 4 / 7$ (b).

the mean repeat time for tsunamis of such intensity range equals to 142 years and, conversely, the mean rate of occurrence, $r$ (in events/yr), becomes 0.007 . It has been shown that a good approximation of the earthquake time distribution in the broad region of the Aegean Sea is Poissonian, that is random (Dionysiou and Papadopoulos, 1992). Assuming that the time distribution of the Mediterranean Sea tsunamis is also Poissonian, as it was suggested by Soloviev (1990) and Papadopoulos (2003), we have that the probability to observe $x$ events in $t$ years is

$P(x)_{t}=\exp (-r t)(r t)^{x} / x !$

and the probability, $P(x \geq 1)_{t}$, to observe at least one event in a time interval of $t$ years is

$P(x \geq 1)_{t}=1-P(x=0)_{t}$

Then, the probabilities to observe at least one tsunami of intensity range $k / K \geq 4 / 7$ within particular time intervals are easily calculated: $7 \times 10^{-3}, 0.30$ and 0.50 for 1,50 and 100 years, respectively.

\section{Conclusions and discussion}

Data on tsunami phenomena occurring in the Hellenic arc and trench system from antiquity up to the present have been updated and critically evaluated. New field observations are presented for the tsunami of 9 February 1948 in Karpathos island while a new tsunami event observed in the city of Rhodes in 24 March 2002 has been documented from field survey. The data were compiled in the standard GITEC format developed in the last decade for the New European Tsunami Catalogue. Eighteen tsunami waves have been reported to have their sources in the east segment of the Hellenic arc and trench system. Eight of them were rather welldocumented while a set of another ten remain doubtful. The mean recurrence of strong tsunamis is likely equal to about 142 years.

The majority of the tsunamis documented are caused by strong earthquakes occurring in the area offshore Rhodes to the east or northeast of the island, which is of particular interest for the tsunami hazard assessment in Rhodes. On the other hand, in that area there are large magnitude earthquakes that do not cause tsunamis. A characteristic example of the instrumental seismicity is the large earthquake of 25 April $1957\left(M_{s}=7.2\right)$ which caused extensive damage in the city of Rhodes and in Fethiye in the opposite coastal zone of Turkey. One day before it was preceded by a very strong foreshock $\left(M_{S}=6.8\right)$ which caused damage in Rhodes. However, none of these two earthquakes was reported to be accompanied by tsunami waves. Consequently, it is of great interest to understand why some Rhodes earthquakes are tsunamigenic and some others are not. This is exactly the problem examined in a forthcoming paper.

Acknowledgements. This paper is part of the research project Tsunami Risk and Strategies for the European Region supported by the CEC, contract number 037058, 6th Framework Programme, FP6-2005-Global-4, Reduction of tsunami risks. The first author is thankful to F. Makri for her help in collecting information about the Karpathos 1948 tsunami and to Th. Dermentzopoulos and A. Ganas for their help during the field trip in Rhodes.

Edited by: S. Tinti

Reviewed by: two referees

\section{References}

Ambraseys, N. N.: Data for the investigation of the seismic seawaves in the Eastern Mediterranean, Bulletin of the Seismological Society of America, 52, 895-913, 1962.

Ambraseys, N. N.: Engineering Seismology, Earthquake Engineering and Structural Dynamics, 17, 1-105, 1988.

Ambraseys, N. N. and Finkel, C .F.: The Seismicity of Turkey and Adjacent Areas, A Historical Review, 1500-1800, EREN Ltd, Istanbul, pp. 240, 1995.

Ambraseys, N. N., Melville, C. P., and Adams, R. D.: The Seismicity of Egypt, Arabia and the Red Sea, Cambridge University Press, pp. 172, 1994.

Amiran, D. H. K., Arieh, E., and Turcotte, T.: Earthquakes in Israel and Adjacent Areas: Macroseismic observations since 100 B.C.E, Israel Exploration Journal, 260-306, 1994.

Antonopoulos, J.: Data from investigation on seismic sea-waves events in the Eastern Mediterranean from the birth of Christ to 1980 AD (6 parts), Annali di Geofisica, 33, 141-248, 1980. 
Baratta, M.: Leonardo da Vinci ed i problemi della terra, Biblioteca Vinciana, Nr. 1, pp. 29, 292-3, Ed. Bocca, Torino, 1903.

Ben-Menahem, A.: Earthquake catalogue for the Middle East (92 B.C.-1980 A.D.), Bollettino di Geofisica Teorica ed Applicata, XXI, pp. 244-313, 1979.

Chatzivasileiou, V.: The catastrophic earthquakes of Ko from antiquity until today, Dodekanisiaka Chronika, H, Athens, pp. 270, 1989.

Coronelli, P. and Parisotti, V.: Isola di Rodi geografica, storica, antica e moderna, Venezia, 1688.

Dionysiou, D. D. and Papadopoulos, G. A.: Poissonian and negative binomial modelling of earthquake time series in the Aegean area, Physics of the Earth and Planetary Interiors, 71, 154-165, 1992.

Evagelatou-Notara, F.: Earthquakes in Byzantium from $13^{\text {th }}$ to $15^{\text {th }}$ century - A historical examination, Parousia, Athens, 24, 1-179 (in Greek with Engl. summary), 1993.

Fokaefs, A. and Papadopoulos, G. A.: Tsunami Hazard in the Eastern Mediterranean: Strong Earthquakes and Tsunamis in Cyprus and the Levantine Sea, Nat. Hazards, doi:10.1007/51169-0069011-3 (http://dx.doi.org), 2006.

Galanopoulos, A. G.: The Seismic Geography of Greece, Ann. Geol. Pays Hellen., 6, 83-121 (in Greek), 1955.

Galanopoulos, A. G.: The seismic sea wave of July 9, 1956, Prakt. Acad. Athens, 32, 90-101, 1957.

Galanopoulos, A. G.: Tsunamis observed on the coasts of Greece from Antiquity to present time, Annali di Geofisica, 13, 369-386, 1960.

Guidoboni, E. and Comastri, A.: The large earthquake of 8 August 1303 in Crete: seismic scenario and tsunami in the Mediterranean area, J. Seismol., 1, 55-72, 1997.

Guidoboni, E., Comastri, A., and Traina, G.: Catalogue of ancient earthquakes in the Mediterranean area up to the $10^{\text {th }}$ century, Pub. Ist. Nazion. Geofisica, Rome, 1994.

Makri, F.: Repatriation of a Karpathian, Rhodes, pp. 79, 1999.

Minoura, K., Imamura, F., Kuran, U., Nakamura, T., Papadopoulos, G. A., Takahasi, T., and Yalciner, A. C.: Discovery of Minoan tsunami deposits, Geology, 28, 59-62, 2000

Montandon: Les tremblements de terre destructeurs en Europe, Catalogue par territoirs seismique, de l' an 1000 à 1940, Geneve, pp. 195, 1953.

Papachristodoulou, X. I.: A History of Rhodes, Municipality of Rhodes-Sereis of Independent Publications, No. 1, Athens, pp. 752, 1994.

Papadopoulos, G. A.: Tsunamis in the East Mediterranean: a catalogue for the area of Greece and adjacent seas, Proc. Joint IOCIUGG International Workshop, "Tsunami Risk Assessment beyond 2000: Theory, Practice and Plans", Moscow, Russia, 14-16 June 2000, Moscow, 2001.
Papadopoulos, G. A.: Tsunami Hazard in the Eastern Mediterranean: strong earthquakes and tsunamis in the Corinth Gulf, Central Greece, Natural Hazards, 29, 437-464, 2003.

Papadopoulos, G. A. and Chalkis, B.: Tsunamis observed in Greece and the surrounding area from antiquity up to the present times, Marine Geology, 56, 309-317, 1984.

Papadopoulos, G. A. and Imamura, F.: A proposal for a new tsunami intensity scale, ITS 2001 Proc., Session 5, No. 5-1, 569577, 2001.

Papadopoulos, G. A., Imamura, F., Minoura, K., Takahasi T., Kuran, U., and Yalciner, A. C.: Strong earthquake and tsunamis in the East Hellenic Arc, Geophys. Res. Abstr. 6, 03212, European Geosciences Union, 2004.

Papazachos, B. C. and Papazachou, C. B.: The earthquakes of Greece, Ziti Edit., Thessaloniki, pp. 304, 1997.

Perissoratis, C. and Papadopoulos, G. A.: Sediment instability and slumping in the southern Aegean 734 Sea and the case history of the 1956 tsunami, Mar. Geol., 161, 287-305, 1999.

Perrey, A.: Note sur les tremblements de terre en 1854, avec suppléments pour les années antérieures 1852-1853, Bull. Acad. R. Sci. Bruxelles, 22, pt. I, 526-572, 1855.

Schmidt, J.: Studien über Erdbeben, Leipzig, 1879.

Sieberg, A.: Untersuchungen uber Bruchschollenban im östlichen Mittelmeergebiet, Denkschriften der MedizinishNaturwissenschaftlichen Gesellschaft zu Jena, 2, Jena, 1932.

Soloviev, S. L.: Tsunamigenic zones in the Mediterranean Sea, Natural Hazards, 3, 183-202, 1990.

Soloviev, S. L., Solovieva, O. N., Go, C. N., Kim, K. S., and Shchetnikov, N. A.: Tsunamis in the Mediterranean Sea 2000 B.C.2000 A.D., Advances in Natural and Technological Hazards Research, 13, Kluwer Academic Publichers, London, 2000.

Tinti, S. and Maramai, A.: Catalogue of tsunamis generated in Italy and in Cote d' Azur, France: a step towards a unified catalogue of tsunamis in Europe, Ann. di Geofisica, 39, 1253-1299, 1996.

Vasiliou, P.: O aftografos "Thrinos tis Theotokou" tou Ioanni Plousiadinou, Ellinika-Publ. of the Society of Macedonian Studies, Thessaloniki, 32, 267-287 (in Greek), 1980.

\section{Press Reports}

Gnomi, 25 March 2002; Dimokratiki, 25 March 2002.

\section{Historical sources}

Agathias, 11.16, 98-100; Aristides Aelius or Poplius, XIII, 340374; Pausanias, VIII 2.7.1 and 43.3; Polyvios, V, 88-90. 